\title{
DESIGN OF A WATER PUMPING SYSTEM FOR A CENTER PIVOT IRRIGATION
}

\author{
Shaimaa MohammadAli, Aml Mohamed, Mohammed Siraj \\ Department of Mechanical Engineering, \\ University of Khartoum, Khartoum - Sudan
}

\begin{abstract}
Center pivot is a method of crop irrigation in which equipment's rotate around a pivot and crops are watered with sprinklers. It is economical, has low operation and maintenance cost and reliable method of irrigation. In this thesis the types of irrigation and pumps is briefly discussed, the fundamental equations of head components are presented, discussed, and calculated. Various design requirements are discussed, pump specifications and power requirements are calculated, and bill of quantities are determined.
\end{abstract}

Keywords: Center Pivot, Irrigation system, water pumping

\section{INTRODUCTION}

Center-pivot irrigation uses less water and labor than many other surface irrigation methods. It has lower labor costs than ground-irrigation techniques that require digging of channels. Also, center-pivot irrigation can reduce the amount of soil tillage. Therefore, it helps reduce water runoff and soil erosion that can occur with ground irrigation. A properly designed irrigation system addresses uniform irrigation application in timely manner while minimizing losses and damage to soil, water, air, plant, and animal resources [1-3]. The design of a conservation irrigation system matches soil and water characteristics with water application rates, to assure that water is applied in the amount needed at the right time and at a rate at which the soil can absorb the water without runoff physical characteristics of the area to be irrigated, in locating the lines and spacing the sprinklers or emitters and in selecting the type of mechanized system, the location of water supply capacity and the source of water will affect the size of pipelines, irrigation system flow rates, size and type of pumping plant to be used must be considered. The power unit selected will be determined by the overall pumping requirements and the energy source available. Determining the right material choice for piping is very important to avoid corrosion and deposition of unwanted chemicals that could severely affect the piping system performance. Desirable materials include but not limited to Alloy 304 SS $[4,5]$ and composite materials [6-11].

The heart of most irrigation systems is the pump; to make an irrigation system as efficient as possible the pump must be selected to match the requirement of water source, water piping system and irrigation requirements.

\section{OBJECTIVES AND GOALS}

To determine the specifications of the pumping unit required to deliver adequately and efficiently amount of water needed to meet the irrigation requirements without over pumping and to determine electric power requirement of the pumping unit.

This includes pumping unit sizing, pump specifications and bill of quantities for supply installation and commissioning of the pumping unit.

\section{METHODOLOGY}

For sizing any pumping system unit, two main characteristics must be known; Required flow rate (obtained from irrigation water requirement data) and required head. The head required composes of the following:

- $\quad$ Static Head (H1).

- Operating Pressure Head (H2).

- Head losses (H3).

Static Head (H1) (elevation head):

It is the elevation difference between the water source and the end sprinkler. When water is pumped from a well, the ground water in the well will drop. This is known as the drawdown. The amount of drawdown depends on the discharge and the water bearing formation surrounding the well. The relationship between the discharge and the drawdown is called the characteristics curve of a well. This is determined by the well drilling company during the pumping test. 


\section{International Journal of Engineering Applied Sciences and Technology, 2020 \\ Vol. 5, Issue 4, ISSN No. 2455-2143, Pages 57-61 \\ Published Online August 2020 in IJEAST (http://www.ijeast.com)}

Elevation difference or Static Head $(\mathrm{H} 1)=($ Eg-Es $)$

+ Hif --------- (1)

Where:

Eg: is the elevation at the end gun in meters,

Es: is the elevation at water surface in the well with the pump in operation,

Hif: is a static head depending on the topography of the irrigated field.

\section{Pressure head (H2):}

The pressure head is the lift associated with the pressure at the end of sprinkler, Pressure is required to spread water to the surrounding area.

$\mathrm{P}=\rho g \mathrm{H}$

$\mathrm{H} 2=\mathrm{P} / \rho g$--------- (2)

Where

$\mathrm{H} 2$ = the pressure head,

$\mathrm{P}=$ the pressure,

$\rho=$ density of water,

$\mathrm{g}=$ gravitational acceleration.

\section{Head Losses(H3):}

Head losses are generally resulting of two mechanisms: Friction along the pipe walls and Turbulence due to changes in streamlines is through fittings and appurtenances. Head losses along the pipe wall are called friction losses or head losses due to friction, while losses due to turbulence within the bulk fluid are called minor losses.

$\mathrm{H} 3=\mathrm{Hf}+\mathrm{Hm}$

Where:

H3= head losses

$\mathrm{Hf}=$ friction losses

$\mathrm{Hm}=$ minor losses

\section{Friction Loss:}

This is the loss of head caused by pipe wall friction and the viscous dissipation inflowing water. It is also called major loss. Estimation of head losses due to friction in pipes is an important task in optimization studies and hydraulic analysis of pipelines and water distribution systems, there are two ways to calculate the friction losses:
1- Darcy-Weisbach equation.

2- Empirical methods.

\section{Darcy-Weisbach Equation:}

$$
h_{f}=\frac{f l V^{2}}{2 g D}
$$

The best equation for computing the frictional head loss in a given pipe for a given discharge

Where:

hf: is the head loss due to friction that has the unit of length.

$\mathrm{f}$ : is a dimensionless friction factor

$\mathrm{L}$ : is the length of the pipe.

$\mathrm{D}$ : is the internal diameter.

$\mathrm{V}$ : is the average velocity.

$\mathrm{g}$ : is the acceleration due to gravity.

The friction factor $\mathrm{f}$ is a function of the Reynolds number and the relative roughness (e/D) which is the internal pipe roughness divided by the pipe diameter. When Reynolds Number (NR) is less than 2000, flow in the pipe is laminar and friction factor is calculated with the following formula: $f=\frac{64}{N_{R}}$

e: Roughness Heights, for certain common Materials

\section{Minor losses:}

Typically, in irrigation systems minor losses are not a large part of the total head requirement. Most times it is good enough to simply add 1.5 to $3 \mathrm{~m}$ to the final friction head calculation as an adjustment for any minor losses which may occur in the system. However, sometimes friction losses in the valves and pipe fittings and other minor losses are taken to be equal to $15 \%$ of the total friction losses in the pipes. [1][2][3][4][5][6]

- The water source is well.

- Friction loss Head (H3f) include:

- Friction loss in the vertical well pipe (H3f1).

- Friction loss in the horizontal pipe extending from well to pivot (H3f2).

- Friction loss in the lateral of the center pivot system (H3f3).

The discharges in the lateral decreases down the pipe towards the end sprinkler because part of the 


\section{International Journal of Engineering Applied Sciences and Technology, 2020 \\ Vol. 5, Issue 4, ISSN No. 2455-2143, Pages 57-61 \\ Published Online August 2020 in IJEAST (http://www.ijeast.com)}

discharge goes out through the sprinklers along the lateral. The friction loss, per unit length of lateral, decreases because of the decrease in pipe discharge. The total friction loss in a lateral must be less than the loss in a corresponding supply line with the same total discharge, diameter, length, and roughness coefficient. It is possible to represent the friction loss in a lateral as a fraction of that in the corresponding supply line $[12,13]$. This is referred to as the friction factor and is 0.543 . The friction loss in the lateral of a center pivot system is, therefore:

$\mathrm{hL}=0.543 \times \mathrm{hf}$

Where

$\mathrm{hL}=$ the friction loss in the lateral,

$\mathrm{hf}=$ the friction loss in the corresponding supply line, in meters.

\section{Pump and motor power requirement equations:}

Total required head is equal to sum of all the heads (Htotal).

The Pump Input Power (Pp) is calculated by the equation:

Pump Input Power $(\mathrm{Pp})=$ Pump hydraulic power (Ph) / Pump efficiency ( $\eta$ )

$\mathrm{Pp}=\rho \mathrm{gQH} / \eta \mathrm{p}$

The driving motor electric power $(\mathrm{Pm})$ is given by the equation:

$\mathrm{Pm}=\mathrm{Pp} / \mathrm{mechanical}$ efficiency $(\eta \mathrm{m})$.

$\rho:$ water density

$\mathrm{H}=\mathrm{H} 1+\mathrm{H} 2+\mathrm{H} 3$

$\mathrm{H}$ : total required head

\section{Sizing the water pumping system}

The following data is given for center pivot irrigation system:

- $\quad$ Pump discharge $(\mathrm{Q})=1300 \mathrm{GPM}=0.082 \mathrm{~m} 3 / \mathrm{s}$

- Well vertical pipe length $70 \mathrm{~m}$ and diameter is 6"

- The lateral is made of two sections:

- Section-1 consists of an outer pipe of length 229 $\mathrm{m}$ and diameter $8 "(=0.2032 \mathrm{~m})$ with an inner PVC pipe of diameter $0.1932 \mathrm{~m}$ (7.606").

- Section-2 consists of an outer pipe of length 171 $\mathrm{m}$ and diameter $6 "(=0.1524 \mathrm{~m})$ with an inner PVC pipe of diameter $0.1424 \mathrm{~m}$ (5.606")
- The Horizontal pipe from well to pivot is of length $420 \mathrm{~m}$ and diameter $10 "(=0.254 \mathrm{~m})$.

- Well Static Water level below ground level $=37$ (39.6) $\mathrm{m}$ and Drawdown $=7$ (10) $\mathrm{m}$

- $\quad$ Pump Level $=108 \mathrm{~m}, 70 \mathrm{~m}$

- The elevation at water surface in the well while the pump in operation (Es) = Well Water level below ground level during pump operation $=44$ $\mathrm{m}$

- The elevation at the end sprinkler (gun) $(\mathrm{Eg})=$ $3.6 \mathrm{~m}$ above the ground

- The static head Hif (which is dependent on the topography of the irrigated field) $=5 \mathrm{~m}$

- Pressure at the end sprinkler $50 \mathrm{psi}=344.7 \mathrm{kPa}$.

\section{CALCULATIONS}

- The head components have been calculated from the equations in the previous chapter

- Elevation difference or Static Head (H1) - equ. $(1)=78.60 \mathrm{~m}$ of water

- Pressure head (H2) - equ. (2) $=35.14$ m of water

- Friction loss of the vertical well pipe (H3f1) equ. (3) $=6.54 \mathrm{~m}$ of water

- Friction loss of the horizontal pipe extending from well to pivot $(\mathrm{H} 3 \mathrm{f} 2)$ - equ. $(3)=3.26 \mathrm{~m}$ of water

- Friction loss of the first four spans of the lateral $=3.66 \mathrm{~m}$ of water

- Friction loss of the last three spans of the lateral $=4.10 \mathrm{~m}$ of water

- Minor Friction Losses in pipe fittings and bends $(\mathrm{Hm})=3.00 \mathrm{~m}$ of water

- The Lift or Total Dynamic Head of the Pumps (H) - equ. $(5)=134.30 \mathrm{~m}$ of water

- The Lift or Total Dynamic Head of the Pumps $(\mathrm{H})+10 \%=147.73 \mathrm{~m}$ of water

\section{Pump and Motor Power Requirements:}

The Pump Station Basic Data are shown in the following table:

\begin{tabular}{|l|l|}
\hline Specification & Description \\
\hline Pump Type & $\begin{array}{l}\text { Continuous Operation } \\
\text { Multi-stage, } \\
\text { Submersible Pump } \\
\text { with 6" diameter } \\
\text { discharge pipe. } \\
\text { Including all fittings, } \\
\text { instruments and safety } \\
\text { devices necessary for } \\
\text { the correct monitoring } \\
\text { and safe and proper } \\
\text { operation of the } \\
\text { pumping unit. }\end{array}$ \\
\hline
\end{tabular}




\section{International Journal of Engineering Applied Sciences and Technology, 2020 \\ Vol. 5, Issue 4, ISSN No. 2455-2143, Pages 57-61 \\ Published Online August 2020 in IJEAST (http://www.ijeast.com)}

\begin{tabular}{|l|l|}
\hline Pump Discharge (Q) & $\begin{array}{l}1300 \text { GPM = 0.082 } \\
\mathrm{m} 3 / \mathrm{s}=295 \mathrm{~m} 3 / \mathrm{hr}\end{array}$ \\
\hline $\begin{array}{l}\text { Pump Lift (Total Head) } \\
\text { (H) }\end{array}$ & $150 \mathrm{~m}$ \\
\hline $\begin{array}{l}\text { Pump Input Power (Pp) } \\
\text { for } \eta p \text { of } \geq 80 \%\end{array}$ & $150 \mathrm{Kw}$ \\
\hline $\begin{array}{l}\text { Electric Power } \\
\text { Required for } \eta \mathrm{m} \text { of } \\
90 \%\end{array}$ & $168 \mathrm{~kW}$ \\
\hline $\begin{array}{l}\text { Well Static Water level } \\
\text { below ground level }\end{array}$ & $37 \mathrm{~m}$ \\
\hline Well Drawdown & $7 \mathrm{~m}$ \\
\hline $\begin{array}{l}\text { Pump installation level } \\
\text { in the well }\end{array}$ & $60 \mathrm{~m}$ below ground \\
\hline $\begin{array}{l}\text { Well Casing inner } \\
\text { diameter }\end{array}$ & $12 "$ \\
\hline
\end{tabular}

The pump shall have the following specifications:

- High efficiency $(>80 \%)$ and high reliability throughout its working range.

- Made of corrosion-resistant stainless steel.

- Sand abrasives resistant.

- Resistant to aggressive water.

- Motor burnout protection.

- Dry-running protection.

- Monitoring and control system for constant optimization of the pumping system.

- Adaptable for installation of additional stages to deliver same discharge at lower installation levels without changing its installed driving motor. (Bidder shall determine the number of stages and that can be added to fulfill this specification at selected lower pump installation levels).

The Electric Motor shall have the following specifications:

- Type: Submersible electric motor for borehole pumps.

- Power: 225 HP/168 KW, 50HZ - 3 Phase $415 \mathrm{~V}$.

- Motor type: Rewind able water filled.

- Winding: with $\mathrm{Pe} 2 / \mathrm{Pa}$ insulation (as the water temperature may reach more than $30 \mathrm{C}$.

- Starting Method: Soft starter.

- Cable size: - 4x240 mm2 + 1x120 mm2 E $\mathrm{cu} / \mathrm{xlpe} / \mathrm{pvc}$ (in conduit suitable for submersible application (length $100 \mathrm{~m}$ ) the actual length must be taken from site /cable length.

\section{CONCLUSION}

Designing and sizing the pumping system for a center pivot irrigation system is the main factor for maximizing the efficiency of the irrigation system and controlling the amount of water delivered to the irrigated area.

In this project, different types of pumps and irrigation systems have been studied including center pivot irrigation pumping system. In order to deliver a proper design of the pumping system; the methods and equations used to calculate the head components (static head; operating head and head losses) in the pump where studied and analyzed. Hazen Williams equation has been used for calculating the head losses.

From the given data of the center pivot irrigation system the head of the water pumping system has been calculated and used to determine the pump characteristics and the power source required.

From the delivered pump and electric motor specifications, a bill of quantities (Supply, Installation and Commissioning) of Water Pumping Unit for Center Pivot Irrigation has been determined.

\section{RECOMMENDATION}

- Solar energy could be used as the power source of the motor to reduce the operating cost of the system.

- The material of the pumping unit parts must have good properties to reduce the maintenance cost and increase the lifetime of the system.

\section{REFERENCES}

1. Dowdy S, Stanley W. Statistics for Research, New York, John Wiley \& Sons, 1982.

2. Fox RW, McDonald AT. Introduction to Fluid Mechanics, New York Wiley, 1992.

3. Giles RV. Theory and Problems of Fluid Mechanics and Hydraulics, New York, Schaum Publishing Co, 1962:274.

4. Kanninen, M. F., Broek, D., Marschall, C. W., Rybicki, E. F., Sampath, S. G., Simonen, F. A., \& Wilkowski, G. M. (1976). Mechanical fracture predictions for sensitized stainless-steel piping with circumferential cracks (No. EPRI-NP-192). Battelle Columbus Labs.

5. Andresen, P. L., \& Ford, F. P. (1988). Life prediction by mechanistic modeling and system monitoring of environmental cracking of iron and nickel alloys in aqueous systems. Materials Science and Engineering: A, 103(1), 167-184.

6. Elamin, M., Li, B., \& Tan, K. T. (2018). Impact damage of composite sandwich structures in arctic condition. Composite Structures, 192, 422-433. 
7. Elamin, M., \& Varga, J. (2020). Plate impact method for shock physics testing. Material Sci \& Eng, 4(1), 31-35.

8. Mohammed, M. (2018). IMPACT AND POST IMPACT RESPONSE OF COMPOSITE SANDWICH STRUCTURES IN ARCTIC CONDITION. (Electronic Thesis or Dissertation). Retrieved from https://etd.ohiolink.edu/

9. Elamin, M., Li, B., \& Tan, K. T. (2018). Impact Performance of Stitched and Unstitched Composites in Extreme Low Temperature Arctic Conditions. Journal of Dynamic Behavior of Materials, 4(3), 317327.

10. Khan, M. H., Elamin, M., Li, B., \& Tan, K. T. (2018). X-ray micro-computed tomography analysis of impact damage morphology in composite sandwich structures due to cold temperature arctic condition. Journal of Composite Materials, 52(25), 3509-3522.

11. TAN, K., ELAMIN, M., \& LI, B. (2017). Impact Performance and Damage Behavior of Composite Sandwich Structures in Arctic Condition. In Proceedings of the American Society for Composites-Thirtysecond Technical Conference.

12. Larock BE, Jeppson RW, Wattes GZ. Hydraulics of Pipeline Systems, New York, CRC Press, 2000. The MathWorks, Inc. Natick, MA.

13. Shames IH. Mechanics of Fluids, Singapore, McGraw-Hill Book Co, 1989:692.

14. Walski TM, Chase DV, Savic DA. Water Distribution Modeling, Waterbury, CT, USA, Haestad Press. 2001. 